Karolina Toka (D)

\title{
Progression or Stagnancy? Portraying Native Americans in Michael Apted's Thunderheart (1992)
}

As argued by Wilcomb Washburn, no other ethnic group has been misrepresented in media and popular culture to such extent as the Native Americans (2010). Movies that shaped their image did so by crystallizing stereotypes and misconceptions, through which indigenous peoples have been perceived until the present day. Thomas Edison's vignettes, early westerns, as well as subsequent motion pictures of the 1960s and 1970s strengthened the stereotypes of the vanishing Indians, bloodthirsty savages, and their noble alter ego. The 1990s brought about a revival of the western in its new, revisionist form, mainly due to the achievements of the American Indian Movement.

This paper argues that the movie Thunderheart (1992) by Michael Apted - albeit belonging to that ostensibly revolutionary current - continues to reproduce various wellestablished stereotypes in the portrayal of the Native Americans . It examines significant achievements of this partly liberal motion picture, as well as its failures and faults. This article argues that Thunderheart departs from traditional, dualistic portrayals of Native Americans as bloodthirsty and noble savages and manages to present a revisionist version of historical events; at the same time, it fails to omit numerous Hollywood clichés, such as stereotypical representation of native spirituality, formation of an "Indian identity", and "othering" of the Native Americans, which contributes to their further alienation and cultural appropriation. This paper provides an insightful analysis of the movie, drawing on scholarship in the field of cultural and indigenous studies in order to lay bare the ambivalence towards indigenous people in the United States, that is reflected in the movie industry. Moreover, it indicates towards the commodification of native culture, as well as the perception of Native Americans as primitive and inferior, allowing to classify Thunderheart as an unfortunate product of colonialism.

Key words: Native Americans, western, revisionist western, film, American film, film studies, Indigenous studies. 


\section{Introduction}

Films have played a significant role in perpetuating misconceptions about numerous ethnic groups. However, as noted by Wilcomb Washburn, attributes that define Native Americans today, more than those of any other group, have been conveyed by cinema - the most powerful medium of the $20^{\text {th }}$ century (Washburn ix). The Native American image has been vastly shaped by captivity narratives, dime novels, and wild west shows, but only with the emergence of cinema, has it become the pervasive, easily digestible portrayal fraught with stereotypes and misconceptions. It has been cinema that encoded the "celluloid Indians" - a set of beliefs and images, beyond which the audiences have not been able to see (Kilpatrick 33). On the one hand, Thomas Edison's first vignettes, presenting Native Americans in their traditional regalia and speaking tribal languages, strengthened the stereotype of "the Vanishing Americans" - exotic creatures dressed in feathers, which were soon to become just historical artifacts. On the other hand, a considerable number of established movies directed by, among others, D.W. Griffith and John Ford constructed detrimental stereotypes of witless, bloodthirsty savages and their alter ego - stoic, spiritual noble savages, living at peace with nature (Jay 8-9; McBride 307-308).

Movies have always reflected the society in which they were produced, but at the same time - as noted by Jeffrey Richards - shaped societal attitudes and beliefs, by virtue of their undeniable propaganda power (Richards xi). Thus, stereotypical portrayals have only strengthened the already existent, biased approaches towards Native Americans. Kilpatrick, for instance, observed that John Ford, more than any other filmmaker, was responsible for ideas about indigenous people that spread throughout society (Kilpatrick 60). Cinematic portrayals affected and exacerbated their relationship with non-native people by fueling racism and prejudice that only contributed to worsening the situation of Native Americans in the United States. Their displacement, poverty on the reservations, constant discrimination, and social deficiencies were in turn the main impetus for native activism during the turbulent time of the 1960's social upheaval. In 1968, the American Indian Movement was founded in order to promote native self-sufficiency and publicize the issues of Native Americans ("American Indian Movement: History, Significance, \& Facts", Encyclopedia Britannica). Since their horrific situation became more tangible, by virtue of cinematic influence, the implications of the movement have found their reflection on the silver screen.

The mid-1960s and early 1970s, therefore, saw a revival of the western in its new, reinterpreted form. Certainly, transformative westerns were recurrent in previous decades with examples such as Duel in the Sun (1946) and The Searchers (1956) but only in the 1960s rebelliousness combined with awakened reverence for Native Americans prompted strenuous efforts to produce innovative and critically minded movies on a larger scale (Bandy and Stoehr 233-234). Revisionist westerns questioned the premises of the genre, mythology of the West, and conventional methods of portraying Native Americans, offering the viewers more ambiguous images (Kasdan and Tavarnetti 121). The genre often reversed the roles of intruders and victims, depicting Native Americans in a more sympathetic way. Subsequent movies produced in the 1990s, which is another decade marking the revival of the western, also 
contributed to the process of demystifying native people, and Thunderheart, directed by Michael Apted in 1992, belongs to that ostensibly revolutionary current.

This paper argues that, in many respects, Thuderheart departs from traditional cinematographic portrayals of indigenous people. Firstly, since it is set in contemporary times, it has managed to portray Native Americans as fully realized human beings, who face problems in their contemporary reality. Secondly, it is inspired by true events and produced in cooperation with the Sioux tribe representatives, which adds to its authenticity. Moreover, the movie stars native actors impersonating diverse, dynamic characters. Thus, Michael Apted foregoes the traditional, stereotypical depictions of native people as a mass of angry savages or phantoms of their past glory. Finally, it presents a revisionist version of history by denuding the FBI's neglect and depicting the harsh living conditions of Native Americans, arising from their turbulent historical relations with Euro-Americans.

Nevertheless, although a considerable number of arguments seem to imply that Thunderheart is a progressive movie, in the second part of this paper, I argue that it draws upon numerous Hollywood clichés in depicting Native Americans. Firstly, indigenous people remain only background characters, subordinated to the FBI agents, who represent the US government coming to their rescue. Thus, it reinforces several old tropes and narrative strategies of the western genre, such as the trope of a white savior or an Indian tracker. Secondly, it covers the controversial issue of selfidentity in a way that reinforces stereotypes about native spirituality and the white desire of "going Indian", introduced in the work of Robert Baird. Additionally, it constructs a sense of otherness, mostly by drawing on a clear distinction between life on the Pine Ridge Indian Reservation and Washington, D.C., which contributes to alienating Native Americans and devaluing them as insufficient citizens. Finally, it attends to the infamous process of cultural appropriation, which reflects the vast ambivalence towards indigenous people in the United States. It appropriates native spirituality and indicates some of the unfortunate products of colonialism, such as the commodification of native cultural components, as well as perception of Native Americans as primitive and inferior.

\section{Noble Intentions: Revising the Image and Forgoing Stereotypes?}

Released in 1992, Thunderheart is a movie directed by Michael Apted, inspired by events that occurred on several Native American reservations during the 1970s, due to the activation of the American Indian Movement. It tells a story of an FBI agent, Ray Levoi, who is sent to the Pine Ridge Indian Reservation in South Dakota (Bear Creek Reservation in the movie) to solve the mysterious murder of a tribal member. Because of the tensions that surface on the reservation, the FBI sends Levoi on the grounds of his partly Sioux heritage, which is expected to be helpful in the investigation. To begin with, he does not feel any sense of belonging to the native community, as he was raised by and entirely assimilated into the Euro-American world. However, once he uncovers the American government's involvement in the murder, in order to suppress uranium mining on the reservation, he teams up with the tribal policeman Walter Crow Horse, in order to uncover the plot and preserve the 
environment on the reservation. Simultaneously, he gradually rediscovers his partly native identity and starts to associate with it.

The movie was received relatively well among the critics. Caryn James from The New York Times called it "entertainment with a social conscience". A substantial number of reviewers discerned the connection between Thunderheart and a documentary movie directed by Apted in the same year, Incident at Oglala, suggesting the former to be a fictional variation of the real story, which would add to its credibility (Turan). On the other hand, as Pack suggests in his article, Thunderheart might have been a product of the fascination with on-screen Native Americans, which was burgeoning in the 1990s, and a temptation to repeat the box office success of Dances with Wolves (1990) (Pack 106). Nevertheless, Dances with Wolves was yet another western set in the timeless Indian past, whereas Thunderheart was a fresh and unprecedented departure from the widespread cinematic schemes. ${ }^{1}$ Unlike the vast majority of movies featuring Native Americans, Thunderheart is set in contemporary times, namely the 1970s. Apted consciously foregoes the clichéd tales about Native Americans, set in the second part of the $19^{\text {th }}$ century, in favor of a refreshing story, which comments on the willful misconduct of the American government. In this regard, it departs from its predecessors since it does not portray Native Americans as vanished entities of the past centuries.

Another element praised by the critics is the movie's casting. Unlike blue-eyed Chuck Connors featuring as Geronimo in 1962, or Charles Bronson playing a Navajo code talker in Never So Few (1959), in Thunderheart all native characters are played by native actors. What is more, a considerable number of them (including Grandpa Sam Reaches, Maggie Eagle Bear, and Jimmy Looks Twice) belong to the Sioux Nation, whose story is being told on screen. Such reflexivity had not been the priority in the 1940s or 1950s - the time when Hollywood fabricated, as described by John A. Price, the widely prevalent and stereotypical representation of Native Americans, in the shape of a horse-riding, buffalo-hunting, feathered warrior of the Plains (Price 153-54). Such development of homogenized "celluloid Indians" was possible because producers did not care about responsible portrayals. In this regard, Thunderheart manages to acquire essential authenticity.

Furthermore, creating distinct Native Americans characters, portrayed as fully realized human beings, might be considered as one of the major achievements of the movie. Walter Crow Horse, played by Oscar nominee Graham Greene, is a jaunty and witty character. Although he has not been sufficiently recognized in the story, he significantly helps Levoi in solving the case, giving him clue after clue (Turan). Maggie Eagle Bear is a college-educated teacher and activist, fighting injustice on the reservation. She remains a strong, dignified, and driven female character throughout the plot. Chief Marvin Thin Elk, starring Grandpa Sam Reaches, is a tribal elder both in the movie and in reality. He is shown to have a sense of humor, in contraposition to stoic Indians, commonly found in most movies. According to Kilpatrick, in earlier motion pictures, Native Americans were "devoid of humor, although humor was often explicitly directed at them" (Kilpatrick 36).

1 The only earlier movie that might be juxtaposed with Thunderheart is Powwow Highway (1989), however it garnered rather a small notice. 
Simultaneously, some of the native protagonists are meant to be the "bad guys": Richard Yellow Hawk, who cooperates with the FBI and the corrupt Milton, responsible for the terror on the reservation. Thus, Thunderheart succeeds in depicting indigenous people as complex, dynamic characters. Last but not least, Jimmy Looks Twice is played by an actual American Indian Movement activist, John Trudell, and even some of his factual quotes are incorporated into the script. Upon his arrested by Levoi and his associate Frank Coutelle, Jimmy says: "I'm a warrior, part of a fivehundred-year resistance. Deep voices that have to be heard. You can kill us, but you can't break our spirit". This particular scene not only stresses Jimmy's tenacity and resistance, but also echoes one of Trudell's famous speeches (Reed 85), thus giving credit to the American Indian Movement (Aboriginal Rights Movement/ARM in the movie).

Having said that, a final achievement of the movie is the significantly progressive way, in which it reconsiders the relationship between the US government and indigenous people, reversing the victim-aggressor scheme. In Thunderheart, the FBI agent Frank Coutelle is involved in illicit dealings on the reservation and partly responsible for the murder, which serves as the cover-up for his actions. As Reed observes, the film draws attention to the economic and environmental consequences of the illegal mining practices that have occurred on the Pine Ridge and other reservations in the last few decades (Reed 85). It has caused a medical and health hazard and has emerged as a flash point for conflicts between indigenous movements and the American government. In an interview to The Christian Science Monitor, Michael Apted admitted that while filming Thunderheart, he aimed to raise awareness of "difficult" matters in American society and politics. He said: "I don't want to harangue people. I tried to avoid hysterical buzz words like 'genocide.' I'd like to make people aware of things in an entertaining manner" (Mason). Film viewers learn about numerous unexplained Indian deaths, which according to some scholars, were the key factor for the foundation of the American Indian Movement (Roos et al. 90). These unsolved murders do not seem to bother FBI as much as the homicide that Levoi and Coutelle come to solve, which eventually emerges to be a part of the plot involving the US government itself.

Most importantly, Thunderheart provides a severely revisionist history, partly representing the events that took place on several Indian reservations in the 1970s. These include malpractices committed by FBI, which one native character in the movie compares to "the second coming of the same old cavalry" (Kvet 373). Apted indicates the legacy of colonial attitudes, which continue to have detrimental consequences on the indigenous people. In addition, the director touches upon the problematic leasing arrangements with corrupt tribal policemen, which allows exploitation of natural resources on the reservations. Such practices, as also depicted in the movie, have had damaging effects on the environment, contaminated water supplies, and have been frequent causes of numerous Native American protests and conflicts with the AIM (Sanchez and Stuckey 123-26). This way, according to Julie Lew, "Old West themes" have been revived, by focusing on the exploration of contemporary indigenous issues, such as the environment and tribal rights, which she sees as "a product of the times" (Lew). Simultaneously, the FBI's critique serves as a visible swing towards the more accurate, revisionist representations of American history in Hollywood. 
What is more, both Michael Apted and screenwriter John Fusco were appreciated for their concern with Native American rights, attempts to resonate the contemporary treatment of Indian nations, and their accurate representations. According to Julie Lew, Fusco was "a lifelong student of American Indian religion and philosophy and is a Sioux honorary adoptee" (Lew). Apted stated that while shooting Thunderheart he cooperated with the tribal elders, who were mainly concerned about the treatment of religious rituals and a honest portrayal of the poverty-stricken reservation (Mason). Janet Maslin of The New York Times appraised the movie as having "the shape of a thriller" with a "documentary's attentiveness to detail" (Maslin). Roger Ebert admitted that the movie provides its audience with "a real visual sense of the reservation, the beauty of the rolling prairie, but also the omnipresent rusting automobiles and the subsistence level of some of the housing" (Ebert). Moreover, the film accurately depicts the spheres of jurisdiction on the reservation - since the 1970s, the Oglala Sioux Tribe has maintained the reservation police, responsible for law enforcement on the reservation; however, it is the FBI that has had jurisdiction over any felony crimes committed on the Indian territory (Deloria and Lytle 183). Nevertheless, since the movie is only inspired by, and not based on true events, as well as all the original names are changed (AIM/ARM, Pine Ridge/Bear Creek), some critics claim that it might have slightly reduced the meaning and importance of the events, by giving them a more fictional character. On the one hand, according to Reed, it undermines the political pull and dimension of the indigenous movement in the movie (Reed 86). On the other hand, such decision might stem from the attempt to unify the experiences shared by several Indian nations around the US and, therefore, present a wider spectrum of the problem.

Having said that, Thunderheart is set in contemporary times, showing the actual issues of the indigenous peoples in the US and denuding the FBI's malpractices. Thus, it provides a revisionist version of history, supporting the thesis that Thunderheart is a progressive motion picture, presenting profoundly changing social attitudes. By placing specific importance on the cast - choosing Native American actors, diversification of the characters, and honest depiction of the tribal realities done in cooperation with the tribal council, the movie departs from traditional cinematographic portrayals, which often simplified the native experience, mocked Indian cultures, and lacked alternative portrayals. Finally, a generally positive reception of the movie indicates a significant shift in the audiences' expectations and heralds winds of change in Hollywood.

\section{Quid Pro Quo: Limitations of the Revisionist Western}

Nonetheless, despite being seemingly innovative, Thunderheart relies upon multiple Hollywood clichés in depicting Native Americans. It serves as evidence that stereotypes about indigenous people, perpetuated in hundreds of movies, have been injected in people's minds to such an extent, that they are almost impossible to reject, in spite of the best endeavors. Hereby, I argue that the movie depicts Native Americans as the other misappropriates their cultural elements, as well as provides strongly ambiguous comments on native spirituality, formation of identity, approach to material values, and contemporary struggles of native people. 
As Sam Pack argues in his article, although native characters are depicted in a diversified, humanistic fashion, their portrayals are still partially rooted in oldfashioned stereotypes that might be quite easily noticeable in the movie (Pack 100). Let the more detailed character analysis serve as acknowledgment of his position. Although Walter Crow Horse has a likeable sense of humor and is an exalted Indian officer, the significant role he plays in solving the murder mystery is rather ignored. At the end of the movie, the viewers are left with the impression that it is Ray Levoi, who answers for the "good ending" of the story. It is him who finds the lottery ticket in the murderer's coat, records Richard giving Frank Coutelle up, and then drives the car to the furtive uranium drilling site at Red Deer Table to successfully finish the plot. Although Walter Crow Horse gives Levoi several traces, which lead him to the final solution, in the chase scene Crow Horse is seen taking off his glasses in a gesture of admiration to Levoi's intelligence and skills, making little of himself. Moreover, Crow Horse is portrayed as an unprofessional police officer. While the FBI agents are investigating the murder scene, they wear the classic attire of dark suits, expensive sunglasses, striped neckties, and sport stylish hairstyles, whereas Walter Crow Horse approaches them on a motorcycle, wearing faded jeans, a denim jacket, a pair of cheap sunglasses, and a cowboy hat, partially covering his long loose hair. In addition to that, he utilizes sensory methods instead of scientific ones. He seems to know the exact amount of the change the murderer had in his pocket, but also his weight and the automobile model. Not only does it undermine the importance of Walter's investigation, but also reinforces the stereotype of "an Indian tracker". While he is essentially the backbone of the successful investigation, he is portrayed only as a sidekick, following the leader .

In his article, Pack compares the Ray Levoi-Walter Crow Horse relationship to that of the Lone Ranger and Tonto (98). According to Robert Siegel, Fran Striker, who is the author of the original Lone Ranger story, developed Tonto "solely for the purpose of giving the Lone Ranger someone to talk to" (Siegel). On the other hand, Donald L. Kaufman states that "whatever the Lone Ranger was, Tonto was less - less fast, less a sharpshooter, less domineering" (Hauptman 90). Even though Walter Crow Horse is undoubtedly an intelligent and capable investigator, helping significantly to solve the case, once Ray Levoi stands on Crow Horse's side, the latter becomes a devoted subordinate, only supporting his superior and dominant partner. This resembles a well-known duet of Indian and cowboy, who are, as Kaufmann observed, "the longest surviving Siamese twins" (34).

Additionally, the Lone Ranger and Tonto duo serves as a cultural metaphor for an imperialist relationship, that conveys Euro-American superiority over Native Americans and therefore, as pointed out by Hartmut Lutz in his article, the inevitable "struggle between civilization and savagery" (34). Thunderheart perpetuates the construction of Native Americans as the "other", by substantially drawing on what Mikhail Bakhtin calls the "genre memory" and the legacy of the most enduring and important relay of American ideology - the western (Burgoyne 42). The film engages in a dialogue with the traditional myths of the West, but at the same time, it relies upon numerous western visual and narrative strategies. According to Robert Burgoyne, the western genre preserves old concepts, while illuminating presentday conflicts and concerns (Burgoyne 48). The movie offers a mythic continuity of clashes between the two civilizations and portrays Native Americans as the separate 
and alienated other, which constitutes the essence of the western genre and American national mythology.

Firstly, in the opening scene of the movie, viewers are introduced to the mythical and mysterious Indian reality. Indians are wearing buckskins and feathers and engaging in a ritualistic dance. While moving in a circular motion, they are accompanied by a rhythmic drumbeat. Later on, they suddenly disappear and the scene shifts to the image of a man running, felled by deathly gunshots to which the background sound of the Indian pipe imparts a sense of anxiety. Thus, the viewers feel immediately struck by the differences of the "other", who is orientalized and exoticized. In the next scene, the audience is quickly invited into an entirely different world, which is enhanced by distinct music (Bruce Springsteen's Badlands playing in the background), as well as the urban landscape of Washington, D.C. The main character, Ray Levoi is driving his brilliant red Mustang convertible through a modern bridge, straight to the FBI's headquarters, where he is soon to be given a new assignment. Young, handsome, and successful, he is a personification of the American dream. The sequence ends with a shot of the Capitol building dominating the US capital city's skyline. Soon, however, once Levoi is given his task and travels to the Bear Creek Reservation, the mise-en-scene, again, changes dramatically. As Levoi and Coutelle enter the reservation they become overwhelmed by the impoverished and dilapidated landscape of the Indian land. The viewers learn of the place's name from a crooked, hanging sign. The somber music in the background is radically different from the dynamic rock single used in the previous scene, which now constructs a sense of concern, fearfulness, and bleakness. Faced with such an image, the agents stay in the safe space of their car, which protects them from the unfamiliar looks of stray people, standing outside their government housing structures. As if the pictures were not enough, Coutelle calls this place the "Third World right here in the middle of America". Ray Levoi, together with the audience, at the very beginning of the movie, is introduced to the dirty and violent reality of Native Americans, who contend with "the highest murder rate in the entire state of South Dakota". The deliberate comments made by Frank Coutelle only emphasize the dichotomy of the two diametrically opposed worlds (Pack 99-100).

Native Americans are depicted as unpredictable, dangerous, and incapable of law enforcement in their own territory. For the white men, Native Americas are Third World refugees with drinking problems and a mess in their yards. Such "symbolic geography" is yet another justification furnished for the FBI's involvement. The agents, however, do not feel welcome here, "a long way from home" (Apted, Thunderheart) and so they treat the very first Native American they encounter, who happens to be a police officer, Walter Crow Horse, quite unwelcomingly. Levoi pushes him violently to the ground, pulls his hair, and sarcastically calls him Geronimo. The first ten minutes of the film particularly emphasize the notion of white people and Native Americans living in two completely different worlds. The opening scenes strengthen the belief that Native Americans are not only different from the FBI agents (who seem to mirror the majority of the Euro-American society), but most importantly, they are lesser beings. Lastly, the comparison of Washington, D.C. - the US capital city and simultaneously one of the richest cities in America - with the Pine Ridge Indian Reservation, which is indeed the poorest region of the country ("Pine Ridge Indian Reservation Facts") seems to be an 
intentional act, collaterally giving salience to the already existent differences and, thus intensifying the sense of indigenous "otherness".

Such alienation and denigration of Native Americans is a prerequisite for the conviction that since indigenous people are lesser beings, the world they live in also operates according to inappropriate and ineffective rules. This is why Thunderheart incorporates the cinematic trope of a white savior. According to Matthew Hughey, a white savior is a white person who helps non-white people. In movies, these white protagonists are usually portrayed as messianic figures, who develop themselves in the course of rescuing non-white characters, naturally devoid of self-sufficiency (Hughey 252). Thunderheart features some of unfortunate products of colonialism, including the paternalistic attitude towards Native Americans. In the $19^{\text {th }}$ century, relations between the American government and indigenous people vastly relied upon a common belief that Native Americans were subhumans, thus they needed to be taken care of. This attitude, although obsolete, transduced into movies and, thus the trope of a white savior is present in a multiplicity of contemporary films, such as Mississippi Burning (1988), Dances with Wolves (1990), The Help (2011), and Avatar (2009) (Sirota). A story line featuring the white savior indicates that the people of color are not capable of standing up for themselves. Simultaneously, it praises the white characters for their benevolence, which may result in inflamed social divisions, racism, and continuous oppression of native people. In Thunderheart the FBI agents are the powerful outsiders, who speak for the indigenous peoples, as if they were in desperate need of help. The paternalistic attitude of the FBI agents is expressed in the statement that Frank Coutelle makes in the movie: "Rightly or wrongly, it's our responsibility because they are incapable of taking care of themselves". This seems to be even more striking, given the fact that the movie tells a story of native resistance, which aimed to stress the importance of native self-determination and erase old paternalistic approaches (Kilpatrick 70). Meanwhile, the very same movie relies on the colonial legacy, preserves differences, and indicates towards the notion of native backwardness. This is in turn is reinforced in one of Levoi's lines: "I just came here from the twentieth century" and his prejudiced offer to show Maggie's grandmother what a plane is: "she can explain to me about the shape-shifting and I will explain her about an airplane". At the same time, the statement seems to be condemned by the way Maggie responds to Levoi, saying that she is a well-educated woman and knows "his world". Nevertheless, although the movie remains quite ambiguous regarding the approach to looking down at the Native Americans, it reinforces the white savior trope and the notion of white supremacy.

White superiority is not only visible in the way Native Americans are treated by the FBI agents, but also in the exceptionalism of the main protagonist, Ray Levoi. At the beginning of the movie, the viewers learn that his dad was a half-breed, which means Levoi is one-quarter Sioux. However, raised outside the reservation and assimilated into the dominant Anglo-Saxon system, he does not identify with his indigenous descent and appears to be ashamed of his Indian blood. When Maggie asks him which tribe he belongs to, he responds: "the United States of America". In another part of the movie, he irredeemably claims: "They are not my people". However, the plot revolves around, what Thomas Reed calls, "the gradual re-Indianization" of Levoi (85). In the film, he progresses toward the new self and begins to sympathize with the native characters as he uncovers Coutelle's conspiracy. Ray's sense 
of solidarity with the Sioux hits a peak when he has a vision, in which he is running away from the white cavalry, side by side with his Indian brothers at Wounded Knee. Later on, Levoi learns from Grandpa Sam that he is the reincarnation of Thunderheart - a medicine man, who died during the 1890's massacre.

Given such a process of re-construction of identity in the movie, a few problems emerge. Firstly, Thunderheart reinforces the common desire of "going Indian", explained in the work of Robert Baird. According to the author, it is "a very old - yet ongoing - process of [...] adoption into the tribal society of the American Indian" (Baird 153). Albeit the American national identity has been shaped as opposed to the indigenously primitive one (Axtell 994-95), Baird proposes the scenario whereby Native Americans are the "true Americans" and thus deserving emulation (154). Therefore, Thunderheart is a carrier of a cinematic myth that comprises still unresolved contradictions of American history and contemporary issues, regarding the conflict between industrialism and environmentalism. It embraces a contemporary fascination with the mystic space and spiritual power of native America and the primitive native way of life that is tempting to the white, more civilized, and developed people. It reinforces the image of a Noble Savage, which according to Lisa Aldred, provides "a fantasy for Euro-Americans wishing to escape dilemmas of their own culture" (341). On the other hand, as Kvet argues in her paper, Thunderheart, unlike Little Big Man or Dances with Wolves, concentrates on the spiritual awakening of a partly Indian protagonist, who had forgotten his ancestry, because of the ongoing cultural assimilation of Native Americans (367-68). Hence, Apted is bringing awareness to a significant issue that indigenous people face, which is the challenge of preserving their identity in a country where they have been forcibly assimilated through multiple governmental programs, such as, for instance, boarding schools. ${ }^{2}$ Therefore, the movie deals with the present problems of the Native Americans, which owe their origins to the turbulent American past, such as the abuse at the hands of corrupt officials, poverty, and exploitation, rather than using Indians only to explore issues related to white America (Kvet 368).

Nevertheless, the phenomenon of "going Indian" contributes to the mockery of native culture through its misappropriation. Not only is Levoi given a choice of accepting his identity and gradually accepted into the Sioux nation, but he also turns out to possess special abilities. Crow Horse says: “A man waits a long time to have a vision, and he may go his whole life without having one. Then along comes some instant Indian with a fucking Rolex and a brand-new pair of shoes, the goddamned FBI to top it all off, has himself a vision". Levoi has "gone Indian" in an extraordinary way - he has become a better Indian than the full-blooded Indians themselves. Moreover, he becomes a hybrid, embodying the best of both worlds (Burgoyne 41). As partly white and partly indigenous, Pack observers, "Levoi has spiritual knowledge of a native elder with all the opportunities of a white man" (105). He has become a man of success

2 From the mid-19th century until as late as the 1960s, native families in the United States were forced to send their children to boarding schools, where the educational programme was designed to extirpate native culture, language, and spirituality. More in: Mary A. Pember, "Death by Civilization." The Atlantic, March 8, 2019. https://www.theatlantic. com/education/archive/2019/03/traumatic-legacy-indian-boarding-schools/584293/, last accessed 22 January 2021. 
because he had been able to leave the reservation and his drunken father. In sum, even after the metamorphosis and the emergence of the native identity, Levoi as a member of the white society, maintains his superiority towards ordinary Native Americans.

Levoi's emerging Indian identity is reinforced by the mise-en-scene. Firstly, Ray Levoi dresses himself as the All-American male - in Ray-Ban sunglasses, expensive watch, a dark suit, and tie. His shoes, as Crow Horse observes, "are a little too tight in the instep, but man, they look cool, and that's what counts" (Kvet 367). However, once Ray rediscovers his native ancestry, he leaves his rich attire in favor of a modest denim jacket, black t-shirt, and jeans, which he wears in the very last scene of the movie. This might be interpreted as an ambiguous commentary on native primitivism and white materialism. In one scene, Levoi barters his precious sunglasses for a rock. Although he does not consider it a fair exchange, he anticipates to earn the trust of Grandpa Sam Reaches. The glasses symbolize an economic position the Native Americans desire, but are unable to achieve because of their backwardness and primitive conditions, which are in turn reinforced through the barter trade. To its credit, Thunderheart explicitly criticizes American consumerism and economic greed. Firstly, through the metamorphosis of the main protagonist; secondly, through the murder that springs from Coutelle's rapacity and the American government's appetite for exploiting the resources on the reservation. However, in accordance with Kvet, Apted uses a rejection of materialism as "a key signifier of Levoi's acceptance of his Indian ancestry" (367), thus juxtaposing white consumerist culture with the uncivilized indigenous way of life. Native Americans in Thunderheart are, following the words of Dr. Josiah Boone in John Ford's Stagecoach (1939), "saved from the blessings of civilization" (Yacavone 32).

The process of reawakening of his Indianness slowly strips away Levoi's materialism, so that at the end of the film, he is able to gladly trade his Rolex with Grandpa Reaches and receive the peace pipe in return (Kvet 367). Out of this particular gesture, some ambiguous interpretations may yet arise. First, as Pack suggests, one may see Grandpa Sam Reaches as a stereotypical Indian wise elder, who disseminates sacred knowledge after smoking the pipe (99). Nonetheless, after the apprehension of Jimmy Looks Twice, Grandpa Reaches cares more about his TV being broken by the FBI agents, rather than the fact that they ridiculed and smashed his 500-year-old turtle rattle. On the one hand, traditional and spiritual Indian; on the other hand, an ordinary, contemporary man, willing to use as many "blessings of civilization" as he wants, however, meticulously renouncing those that he does not need. Second, exchanging the peace pipe, a religious item, for a watch, which is, according to Pack, "the personification of Western indulgence" (102) trivializes native spirituality by making it transmutable into a commodity. Lisa Aldred has observed that "the fetishization of the Noble Savage [...] accounts for this increased commercial consumption of Native American spirituality since the 1980s" (342), which results in "spiritual hucksterism". ${ }^{3}$ Following this line of thought, one might interpret it as

3 Glorifying the native spirituality in films contributes to the emergence of so called "plastic medicine men" - non-native individuals, who sell "Indian wisdom" for a fee. One of the prominent examples is the Bear Tribe Medicine Society, which engages in the sale of native ceremonies and sacred objects, thus Native American spirituality and handcraft have become a product to be purchased in the marketplace. [in:] (Pack 102) 
a moral contamination having drifted into native societies together with American imperialism and consumerist ideology the impact of which turns out to be stronger than centuries-old traditions and religious rituals. On the other hand, the elder might have gifted the pipe to Levoi as a symbol of his acceptance into the Sioux community, which believes this item to be necessary for communication with the supernatural world, while Sam is given the watch to use it for more practical purposes. Thus, this scene could be interpreted in two ways - both as a critique of the obscene, money-oriented American greed and as a reversal of the roles traditionally assigned to indigenous and white communities.

\section{Conclusions}

Thunderheart represents the affection for 'all what constitutes "Indian"' for the white mainstream society, thus typifying the revival of movies featuring Native Americans in the 1990s. Despite the honest attempts to present Native Americans (in a movie that tells their story) in an enlightened manner, to some degree, as Pack argues, "all representational accounts of Native Americans by nonnative Americans are rooted in paternalism" (110). It implements the unquestioned assumption that Westerners are able to discover and report the truth about native cultures and that native people are not capable of speaking for themselves. Moreover, the film's portrayal of the Lakota nation is filled with references to and intimations of the past, which reinforces the image of "the Vanishing Americans". It is deeply disturbing when native people are forced to make the choice between stereotypes and misrepresentation, or their utter invisibility, which rationalizes Indian participation in movies perpetuating their stereotypical depictions.

On the other hand, unlike many previous films, Thunderheart, as stated in the first part of this paper, succeeds in portraying Native Americans as contemporary, fully realized people with a sense of humor and dynamic characters. It presents the diversity of their culture and the complicated history of relations with Euro-Americans, previously mistakenly reduced to just a few decades of the $19^{\text {th }}$ century (Kempna-Pieniążek 102). As Magdalena Kempna-Pieniążek argues, it was only the efflorescence of the authors of indigenous origin, who introduced a new perspective to the film industry, questioned ridiculous stereotypes by the application of irony and could hold a discussion deprived of mysticism and sentimentality, but account for the point of view of a modern Indian and an American (102-03). However, Thunderheart is still focused on Levoi - an equation of the white world and his appropriation of the native identity. Native Americans are presented in the movie as the "other", whose primitive way of life does not tackle the challenges of the modern world, therefore the white saviors are needed to come and save the Indian nation from its plight.

The movie evinces the tendency to portray Native Americans as too good and the white people as too evil. Thus, it generates new, yet still stereotypical perceptions, which accounts for a constant alienation of the indigenous peoples. Simultaneously, it raises significant issues such as the poverty-stricken reality of the reservation, exploitation of the native lands, corruption, and the struggle to preserve the native identity, which had been eradicated by the US government. Thus, Apted skillfully comments on American economic greed, rotten materialism, and abuse, suggesting 
that capitalism is a new method of colonizing native people. Tag Gallagher argues that white producers have never managed to fully appreciate native culture and history and presented it in an irresponsible and inauthentic way (484). Nevertheless, although Apted's motion picture, as argued in this paper, in many aspects fails to provide a depiction of Native Americans that would be deprived of all disputable elements, it undoubtedly challenges the viewers to reflect upon the return to full sovereign status of the Indian nations, restoration of lands guaranteed by treaties, compensation for the minerals exploited from reservations, and a righteous treatment of native resistance.

\section{References}

Aldred, Lisa. "Plastic Shamans and Astroturf Sun Dances: New Age Commercialization of Native American Spirituality." The American Indian Quarterly, vol. 24, no. 3, 2000, pp. 32952, https:// doi.org/10.1353/aiq.2000.0001.

"American Indian Movement | History, Significance, \& Facts." Encyclopedia Britannica, https://www.britannica.com/topic/American-Indian-Movement, last accessed 10 January 2021.

Apted, Michael. Incident at Oglala. Spanish Fork Motion Picture, Wildwood Enterprises, 1992. $I M D b$, https:/ / www.imdb.com/title/tt0104504/, last accessed 22 January 2021.

-. Thunderheart. TriStar Pictures, 1992.

Axtell, James. "Colonial America without the Indians: Counterfactual Reflections." The Journal of American History, vol. 73, no. 4, March 1987, https:/ / doi.org/10.2307/1904058.

Baird, Robert. "'Going Indian': Dances with Wolves." Hollywood's Indian: The Portrayal of the Native American in Film, by Peter C. Rollins and John E. O'Connor, Lexington, KY: University Press of Kentucky, 2010.

Bandy, Mary Lea and Stoehr, Kevin. Ride, Boldly Ride: The Evolution of the American Western. Berkeley, CA: University of California Press, 2012.

Burgoyne, Robert. Film Nation: Hollywood Looks at U.S. History. Minneapolis, MN: University of Minnesota Press, 1997.

Deloria, Vine and Lytle, Clifford M. American Indians, American Justice. Austin, TX: University of Texas Press, 1983.

Ebert, Roger. "Thunderheart: Review." The Chicago Sun, 3 April 1992, https:/ / www.rogerebert.com/reviews/thunderheart-1992, last accessed 22 January 2021.

Gallagher, Tag. John Ford: The Man and His Films. Berkeley, CA: University of California Press, 1988.

Hauptman, Laurence M. Tribes and Tribulations: Misconceptions about American Indians and Their Histories. Albuquerque: University of New Mexico Press, 1995.

Hughey, Matthew W. The White Savior Film: Content, Critics, and Consumption. Philadelphia: Temple University Press, 2014.

James, Caryn. “One Director, Two Routes To American Indian Travail." The New York Times, 10 May 1992. NYTimes.com, https:// www.nytimes.com/1992/05/10/movies/film-viewone-director-two-routes-to-american-indian-travail.html, last accessed 22 January 2021.

Jay, Gregory S. 'White Man's Book No Good': D.W. Griffith and the American Indian." Cinema Journal 2000, vol. 39, no. 4 (Summer), pp. 3-26, https:/ / doi.org/10.1353/cj.2000.0016.

Kasdan, Margo and Tavarnetti, Susan. "Native Americans in a Revisionist Western: Little Big Man (1970)." Hollywood's Indian: The Portrayal of the Native American in Film, by Peter C. Rollins and John E. O'Connor, Lexington: University Press of Kentucky, 2010.

Kaufmann, Donald L. “The Indian as Media Hand-Me-Down," in: Bataille, Gretchen M., and Silet, Charles L. P. (ed.) The Pretend Indians: Images of Native Americans in the Movies, Iowa City: Iowa University Press, 1980. 
Kempna-Pieniążek, Magdalena. “Twórczość Chrisa Eyre’a w kontekście problemów filmowych adaptacji." Annales Universitatis Paedagogicae Cracoviensis | Studia de Cultura, vol. 5, no. 135, April 2013, pp. 94-105.

Kilpatrick, Jacquelyn. Celluloid Indians: Native Americans and Film. Lincoln, NE: University of Nebraska Press, 1999.

Kvet, Bryan W. Red and White on the Silver Screen: The Shifting Meaning and Use of American Indians in Hollywood Films from the 1930s to the 1970s. Kent, OH: Kent State University, 2016.

Lew, Julie. "Hollywood's War on Indians Draws to a Close." The New York Times, 7 October 1992.

Lutz, Hartmut. "Indians' and Native Americans in the Movies: A History of Stereotypes, Distortions, and Displacements." Visual Anthropology, vol. 3, no. 1, 1990, pp. 31-48, https:// doi.org/10.1080/08949468.1990.9966521.

Maslin, Janet. "Val Kilmer as an F.B.I. Agent Among the Sioux." The New York Times, 3 April 1992. NYTimes.com, https://www.nytimes.com/1992/04/03/movies/reviewfilm-val-kilmer-as-an-fbi-agent-among-the-sioux.html, last accessed 22 January 2021.

Mason, M. S. “Director Tries to Balance Native American Concerns.” The Christian Science Monitor, May 1992. Christian Science Monitor, https:/ / www.csmonitor.com/1992/0512/12112. html, last accessed 22 January 2021.

McBride, Joseph. Searching for John Ford. Jackson Miss.: University Press of Mississippi, 2011.

Pack, Sam. "The Best of Both Worlds: Otherness, Appropriation, and Identity in Thunderheart." Wicazo Sa Review, vol. 16, no. 2, 2001, pp. 97-114, https://doi.org/10.1353/wic.2001.0028.

"Pine Ridge Indian Reservation Facts." Re-Member, https://www.re-member.org/pineridge-reservation.aspx, last accessed 29 January 2020.

Price, John A. "The Stereotyping of North American Indians in Notion Pictures." Ethnohistory, vol. 20, no. 2, 1973, pp. 153-71, https:/ / doi.org/10.2307/481668.

Reed, Thomas Vernon. "Old Cowboys, New Indians: Hollywood Frames the American Indian." Wicazo Sa Review, vol. 16, no. 2, 2001, pp. 75-96.

Richards, Jeffrey. "General Editor's Preface." Hollywood Goes to War: Films and American Society, 1939-1952, by Colin Shindler, Abingdon-on-Thames: Routledge, 2014.

Roos, Philip D. et al. "The Impact of the American Indian Movement on the Pine Ridge Indian Reservation." Phylon (1960-), vol. 41, no. 1, 1980, pp. 89-99.

Sanchez, John and Stuckey, Mary E. "The Rhetoric of American Indian Activism in the 1960s and 1970s." Communication Quarterly, vol. 48, no. 2, Mar. 2000, pp. 120-36, https://doi. org/10.1080/01463370009385586.

Siegel, Robert. "The Lone Ranger: Justice from Outside the Law." National Public Radio, January 2008, https://www.npr.org/templates/story/story.php?storyId=18073741, last accessed 22 January 2021.

Sirota, David. "Oscar Loves a White Savior." Salon, Feb ruary 2013, https://www.salon. com/2013/02/21/oscar_loves_a_white_savior/, last accessed 22 January 2021.

Turan, Kenneth. "Vision Quest of 'Thunderheart.'” Los Angeles Times, 3 April 1992, https:/ / www.latimes.com/archives/la-xpm-1992-04-03-ca-0-story.html, last accessed 22 January 2021.

Washburn, Wilcomb E. "Foreword." Hollywood's Indian: The Portrayal of the Native American in Film, by Peter C. Rollins and John E. O'Connor, Lexington, KY: The University Press of Kentucky, 1998, pp. 153-71.

Yacavone, Peter. "'Free From the Blessings of Civilization': Native Americans in Stagecoach (1939) and Other John Ford Westerns." Film \& History: An Interdisciplinary Journal, vol. 48, no. 1, 2018, pp. 32-44. 